\title{
Devatero přikázání pro všechny členské země EU, čtvero dalších pro Českou republiku
}

\author{
Eva Klvačová ${ }^{1}$
}

\begin{abstract}
Přistoupení deseti nových členských států představuje historickou šanci. Současní členové se mohou poučit z impozantního rozsahu a kroků reforem, jimiž tyto ekonomiky prošly, avšak proces učení musí být oboustranný. Výzvy nově přistupujicích zemí se v zásadě neliši od výzev nových členských států s tím, že musí být založeny na urychlení reálné konvergence.
\end{abstract}

Výbor EU pro hospodářskou politiku

Změny, jimiž prošla česká společnost a česká ekonomika v období posledních pěti let, lze shrnout pod jednoho společného jmenovatele: příprava na nadcházející vstup České republiky do Evropské unie a institucionální, politické, ekonomické a sociální důsledky s touto př́ípravou související. Žádná jiná změna českou společnost nepoznamenala ve srovnatelné mî́re, žádná jiná změna uskutečněná v daném období nemá pro budoucnost české společnosti a budoucnost její ekonomiky větší význam.

Implementace acquis communautaire do české legislativy, která byla nutnou podmínkou vstupu a která ve sledovaném období probíhala, znamenala pro Ceskou republiku ve své podstatě jakousi druhou fázi ekonomické a společenské transformace. Zatímco první fáze, kterou můžeme ohraničit obdobím od politické změny v roce 1989, byla ve své podstatě přechodem od centrálně plánované ekonomiky k ekonomice tržně orientované a od společnosti centralisticky řízené ke společnosti demokratické, pak druhou fázi, jejiž počátek spadá do počátku prŕípravy na členství ( rok 1998), lze chápat jako období institucionální, politické, ekonomické a sociální kultivace, jako období přibližování pravidel platných v České republice pravidlům platným ve vyspělých evropských zemích.

Úloha českého státu ve společnosti a v ekonomice je v současné době v Česká republice ve své normativní podstatě stejná jako v zemích EU, stejná je normativní podstata pravidel chování pro podnikovou sféru, pro vztah státu a malých, středních i velkých podniků, pro vztah státu a občana v jeho jednotlivých sociálních rolích, pro vztah zaměstnance a zaměstnavatele, spotřebitele a výrobce. Určitý rozdíl zůstává ve vymahatelnosti platných pravidel - zákonů, to však nic nemění na skutečnosti, že všechny zásadní změny ve směru efektivní regulace sofistikované sociálně-tržní ekonomiky byly již učiněny.

O prospěšnosti či naopak škodlivosti přijetí institucionálního rámce platného v Evropské unii pro Českou republiku z hlediska výkonnosti její ekonomiky se diskutovalo po celé přípravné období až do okamžiku samotného vstupu.

1 Doc. Ing. Eva Klvačová, CSc., vedoucí Institutu integrace ČR do evropské a světové ekonomiky, docentka Katedry mezinárodního obchodu Fakulty mezinárodních vztahů Vysoké školy ekonomické v Praze. 
Přívrženci vstupu argumentovali, že institucionální konvergence je nutnou podmínkou konvergence reálné. Ekonomika země s nedokonalými, neadekvátními institucemi není definičně schopna dosahovat stejně dobrých výsledků jako ekonomika s institucemi kvalitními, přiměřenými. Moderní sofistikovaná tržně orientovaná ekonomika nemůže fungovat bez kvalitní ochrany vlastnických práv, bez účinné regulace finančních trhů, bez pravidel hry pro hospodářskou soutěž, bez transparentních a jednoznačných norem chování pro vztah státu a podnikové sféry, bez transparentních a jednoznačných norem pro vzájemné vztahy podnikatelských subjektů i vztahy podnikatelských subjektů k občanům v jejich jednotlivých sociálních rolích (spotřebitel, zaměstnanec, klient bankovního ústavu aj.).

Odpůrci vstupu argumentovali vysokou mírou byrokratičnosti EU, omezováním míry občanské i podnikatelské svobody, omezováním demokracie. Zdůrazňovali, že vstup ČR do EU přinese podnikatelské sféře takové zvýšení nákladů, které bude znamenat snížení konkurenceschopnosti domácích podniků, zvýšené nebezpečí úpadků a rychlý růst nezaměstnanosti.

Před úspěšným referendem se s vysokou četností objevovaly nejen v denním tisku a ostatních médiích, ale i v odborných časopisech názory a stanoviska, jejichž společným jmenovatelem byl pozitivní vztah k společnému trhu na jedné straně a negativní vztah k potenciálnímu sbližování hospodářských a sociálních politik, k společnému rozpočtu, k regulační úloze Evropské unie a k politické integraci na straně druhé. Bylo možno pozorovat i tendenci k zjednodušování a vulgarizaci argumentů, k vytváření jakési karikatury Evropské unie a následnému názorovému střetu nikoli s reálným obsahem evropských dokumentů a doporučení Evropské komise, ale právě s touto karikaturou. Př́íkladem tohoto druhu může být článek Petra Macha, analytika a současného výkonného ředitele Centra pro ekonomiku a politiku „Vstup do EU by omezil svobodu občanů“, v němž se uvádí mimo jiné: Česká republika bude do společného rozpočtu odvádět částku minimálně 25 miliard korun a česká vláda doufá, že zpět z EU dostaneme minimálně stejnou částku, abychom netratili. Vzhledem k tomu, že EU spotřebovává 5 \% jen na vlastní administrativu, je velmi nepravděpodobné, že bychom dlouhodobě dostávali více než dávali...Dřive nebo později bychom dopláceli nejen na bruselskou byrokracii, ale také na francouzské či polské zemědělce a řecké či slovenské silnice... Společná legislativa, to jsou direktivy a regulace vydávanév Bruselu, a každá z nich znamená z podstaty omezení svobody. Brusel nám bude diktovat, kolik smíme vyrábět bramborového škrobu a kolik se u nás smí pěstovat prasat. Bude nám diktovat, jak smějí být velké klece v drůbežárnách, jak hlučné smějí být mixéry, jak dlouhá musí být záruční doba, jestli se u nás smí prodávat acylpyrin nebo jak velké musí být daně. Vliv českých zástupců na tuto legislativu bude zanedbatelný, budeme tak plnit prání jiných...Nadnárodní Evropská unie z podstaty znamená paralýzu demokracie. Národní volby se stanou fraškou, protože at' vyhraje v ČR volby kdokoli, evropská demokracie bude zůstávat stále průměrná...V nadnárodní Evropské unii budou pošlapávána práva jednotlivců jedněch národů ve prospěch jednotlivců jiných národů... "²

V méně emotivní podobě, s větším akcentem na ekonomickou stránku vstupu ČR do EU a s voláním po dostatečně dlouhém přechodném období se obavy z integrace objevily i ve studii „Sociální a ekonomické dopady integrace České republiky do Evropské unie (Nové př́ležitosti, možná rizika“, kterou zpracoval početně rozsáhlý kolektiv autorů podle zadání Rady vlády pro ekonomickou a sociální strategii v letech 2000 - 2001.

Studie projevila své obavy takto: „Základním rizikem při vstupu do Evropské unie je stále ještě nízká úroveň konkurenceschopnosti české ekonomiky. Kreálné konvergenci bude nutné dostatečně dlouhé období k překlenutí široké propasti mezi Českou republikou a vyspělými

2 Laissez faire, listopad 2002. 
státy EU. V tomto období, následujícím po vstupu do EU, musí rovněž dojít k vyrovnání mnohonásobných cenových rozdílů, jinak bude levná pracovní síla bránit nutnému procesu náhrady živé práce... Dalším rizikem je prudši cen potravin...Nepůjde o mimořádný cenový šok, lze jej rozložit tak, aby míra inflace v průběhu let 2000 - 2010 nepřsáhla 5 - 7 \% ročně. Přesto dopad do konkurenceschopnosti podniků, mzdových vyjednávání, resp. zaměstnanosti může být citelný... Zvýšené náklady, spojenés príijetím acquis communautaire v oblasti ochrany životního prostředí, predstavují riziko většího schodku veřejných rozpočtů ...Implementace standardů ES v bezpečnosti a ochraně zdraví při práci, v sociální politice, $v$ životním prostředí, v oblasti nepř́mých daní, v oblasti zabezpečení zdraví a pohodlí zvírat a vodpadovém hospodářství vyvolá zvýšené náklady podnikatelskésféry. Ten byl dosud naprosto nedoceňován..."

Prvního května 2004 se Česká republika stala členem Evropské unie. Je na místě podívat se, do jaké míry se naplnily obavy odpưrců vstupu. Určitou výpovědỉmůže podat jednak vývoj hodnot některých základních indikátorů ekonomického a sociálního vývoje České republiky v letech př́ipravy na vstup do EU v konfrontaci s vývojem v období mezi ukončením ekonomické transformace a začátkem přípravy na vstup (v kontextu mezinárodního porovnání), jednak soubor doporučení směřujících od Evropské unie k České republice.

\section{Konvergence, nebo divergence?}

Změny v ekonomice ČR za období od podání přihlášky ke vstupu do EU nejsou př́liš výrazné, nicméně lze z nich vysledovat trendy převážně pozitivní. Vypovídá o nich v prvé řadě vývoj hodnot jednotlivých strukturálních indikátorů používaných Evropskou komisí pro pravidelné vyhodnocování pokroku v naplňování cílů Lisabonské strategie a zveřejňovaných Eurostatem.

Obecné ekonomické prostředí je charakterizováno hrubým domácím produktem na obyvatele v paritě kupní síly v relaci k průměru zemí Evropské unie (EU $15=100)$. Eurostat uvádí hodnoty tohoto indikátoru za posledních deset let, od roku 1994 do roku 2003. Nejsou zde tedy zahrnuta období, kdy v rámci ekonomické transformace došlo v dnešních nových členských zemích EU k hlubšímu nebo mělčímu propadu hrubého domácího produktu. Časová řada uváděná Eurostatem pro Českou republiku je bohužel podstatně kratší, sahá zpět pouze k roku 2000. Je z ní patrné, že v hodnotách daného ukazatele docházelo k mírné konvergenci ČR k zemím evropské patnáctky. Jestliže v roce 2000 činil HDP na obyvatele v paritě kupní síly 59,7 \% průměru zemí EU, pak v průběhu celého období docházelo k mírnému nárůstu hodnoty tohoto indikátoru. V roce 2003 činila hodnota tohoto indikátoru $62,7 \%$. Nepotvrdila se tedy - alespoň pro dané období - hypotéza o nepříznivém vlivu přijetí institucionálního rámce Evropské unie na ekonomickou aktivitu a o př́šstím vzdalování se zemím EU. Konvergence bylo dosaženo díky předstihu tempa růstu HDP ve stálých cenách v ČR oproti tempu růstu úrovně stejného indikátoru v zemích evropské patnáctky (o 1,0 až 1,5 procentního bodu). Ve směru konvergence hodnot daného indikátoru působila ovšem i stagnace, resp. pokles počtu obyvatelstva v ČR - na rozdíl od jeho růstu v EU.

Je přirozeně nutno zdůraznit, že ve srovnání se státy Evropské unie zůstala ekonomická úroveň ČR oproti státům evropské patnáctky stále významně nižší. Za nejslabším členem EU - 15, Portugalskem, zaostávala ČR v roce 2003 o cca 6 procentních bodi̊, za Reckem o cca 11 procentních bodů. $V$ porovnání s ostatními kandidátskými zeměmi zaujímá česká ekonomika čtvrté místo za Kyprem, Slovinskem a Maltou. Za ní následuje Mad'arskos odstupem 8 procentních bodů. Rychlost konvergence většiny ostatních kandidátských zemí byla větší než rychlost konvergence české ekonomiky. Např́íklad Estonsko 
zvedlo úroveň relace svého HDP na obyvatele v paritě kupní síly z 37,8 \% v roce 2000 na $42,2 \%$ v roce 2003, Mad'arskcz 47,9 \% na 55,3\%, Polsko z 23,2 \% na 28,7 \%. Naopak Malta zaznamenala za sledované období divergenci a Kypr stagnaci. Projevil se zde tedy efekt dohánění: rychleji konvergovaly k průměru evropské patnáctky kandidátské země s nižší ekonomickou úrovní, pomaleji země s úrovní vyšší. Česká republika patřila k zemím druhé skupiny.

Na základě desetileté časové řady lze dokumentovat, že ke konvergenci hrubého domácího produktu v paritě kupní síly na jednoho obyvatele k zemím evropské patnáctky docházelo u všech nových členských, dřive tranzitivních zemí. Tento výrok platí pro Estonsko (vzestup z 30,8 \% na 43,3 \% průměru EU-15 během deseti let), Litvu (z 27,8 \% na 43,6 \%), Lotyšsko (z 26,6 \% na 36,7 \%), Mad'arsko(z 46,3 \% na 54,9 \%), Polsko (38,5 \%), Slovinsko (z 62,5 \% na 70,6 \%) i Slovensko (z 45,4 \% na 48,2 \%). Konvergence se v souvislosti s implementací acquis communautaire do zákonů nově přistupujících zemí výrazně nezrychlila ani nezpomalila. Podstatně významnější vliv po celou dobu měl efekt dohánění. Jeho působení lze dokumentovat nepřímo mimo jiné na dvou nových členských zemích EU z řad zemí netranzitivních: Kypru a Maltě. Ty vstupovaly do EU s podstatně vyšší ekonomickou úrovní než všechny tranzitivní země a relace jejich HDP na obyvatele v paritě kupní síly k průměru zemí evropské patnáctky víceméně stagnovala.

K mírné konvergenci k úrovni evropské patnáctky docházelo v české ekonomice rovněž v oblasti produktivity práce na zaměstnance měřené jako hrubý domácí produkt v paritě kupní síly na zaměstnanou osobu v relaci k EU - 15 . Hodnota tohoto indikátoru pro ČR činila na počátku sledovaného období, v roce 2000 52,7 \%, v roce 2003 pak 54,8 \% úrovně zemí evropské patnáctky. Vyšší produktivitu práce na zaměstnance než Česká republika měly v roce 2003 nejen všechny země evropské patnáctky včetně zemí nejméně vyspělých, ale z bývalých tranzitivních zemí i Slovinsko, Mad'arsko a Slovensko.

Rychlejší růst spotřebitelských cen vedl $k$ postupnému přibližování cenové hladiny v České republice cenové hladině průměru zemí evropské patnáctky. V letech 2000 - 2002 vzrostla cenová hladina spotřeby domácností ze 45,3\% úrovně EU - 15 na 53,1 \% EU 15. Trend k přibližování cenové hladině zemí evropské patnáctky je možné pozorovat víceméně u všech nově přistoupivších, dříve tranzitivních zemí. Časová řada není bohužel pro všechny tyto země dostatečně dlouhá, aby bylo možno potvrdit, nebo vyvrátit hypotézu, že implementace acquis communautaire působila ve směru zrychlení růstu cenové hladiny vzhledem k nutnosti podnikové sféry promítat do cen náklady související s vyšším stupněm ochrany spotřebitele, vyšším stupněm ochrany zdraví při práci, vyššími nároky na ochranu životního prostředí atd. Data za pobaltské země, která sahají zpět k roku 1995, hovoří spíše proti validitě této hypotézy. Přibližování cenových hladin probíhalo v období přípravy na vstup do EU pomaleji než v předcházejících letech. Pokud jde o Slovinsko, poměr cenové hladiny k cenové hladině EU zůstával víceméně konstantní. K určitému zrychlování přibližování cenových hladin docházelo v období př́ípravy na vstup do EU v Mad'arskua na Slovensku.

Míra inflace je sledována v rámci strukturálních indikátorů prostřednictvím harmonizovaných indexů spotřebitelských cen. Eurostat uvádí tyto indexy pro období od roku 1992, data však nejsou dostupná pro všechny země. Pro většinu nových členských zemí jsou k dispozici od roku 1996. Lze tedy porovnat míry inflace v období předcházejícím přípravě na členství v EU přejímáním acquis communautaire s obdobím přípravy. Pokud jde o Českou republiku, jednoznačně platí, že míra inflace v období přípravy na členství nevzrůstala, nýbrž klesala. Až do roku 1998 se pohybovala na úrovni těsně pod deseti procenty, $\mathrm{v}$ dalších letech spadla hluboko pod tuto úroveň a v roce 2003 zaznamenala rekordně níz- 
kou úroveň -0,1\%. Obdobný vývoj - pokles míry inflace v období př́ípravy na členství v EU - zaznamenaly všechny nové členské, dříve tranzitivní země s výjimkou Slovenska. Nejžretelněji je tento vývoj patrný u pobaltských zemí. V nich se ještě v roce 1996 míra inflace pohybovala kolem dvaceti procent, v současné době je nižší (Estonsko 1,4\% v roce 2003) nebo mírně vyšší (Lotyšsko 2,9 \%, Litva $4,0 \%$ v roce 2003) ve srovnání s průměrem evropské patnáctky, který činí $2,0 \%$. Vývoj míry inflace v nových členských zemí svědčí ve prospěch hypotézy, že výdaje spojené s implementací acquis a vyššími nároky na ochranu zdraví, spotřebitele, životního prostředí atd. neměly zásadní význam pro růst nákladů a byly vykompenzovány př́nosy z titulu úspor na sjednocení institucionálního rámce pro podnikatelské aktivity a vyčištění podnikatelského prostředí oproti období ekonomické transformace.

Míra zaměstnanosti vyjádřená jako podíl počtu zaměstnaných osob ve věku 15 - 64 let na počtu obyvatelstva stejné věkové skupiny se v České republice v průběhu sledovaného období nezměnila. Činila $65 \%$, což je nepatrně vyšší úroveň než jaká je dosahována zeměmi evropské patnáctky (64\%), ale nižší než například úroveň dosahovaná Rakouskem (69 \%). Za zmínku stojí, že Rakousko patří k zemím, které již dnes splňují stř̌ednědobý cíl Lisabonské strategie zvýšit míru zaměstnanosti do roku 2005 na 67 \% (vyšší než cílovanou míru zaměstnanosti mají již dnes zejména Dánsko, Nizozemsko, Švédsko či Spojené království). Pokud jde o nově přistupující země, budou mít zřejmě všechny větší problémy s naplněním tohoto cíle než ČR. Pokud jde o zvlášt sledovanou míru zaměstnanosti žen, dosahuje ČR rovněž vyšší hodnoty než činí průměr EU (57\% oproti 55,6\%). Nad úroveň EU se v uplynulých čtyřech letech dostala v České republice i míra zaměstnanosti starších pracovníků ve věku 55 - 64 let (v zemích evropské patnáctky činila 40,1 \%,v ČR 40,8 \%).

Hrubé domácí výdaje na výzkum a vývoj jsou významnou charakteristikou inovativních schopností země a jedním z indikátorů sledovaných Eurostatem. Evropská unie si vytkla za cíl zvýšit do roku 2010 podíl výdajů na výzkum a vývoj na hrubém domácím produktu ze současných $2 \%$ na $3 \%$ (1 \% z veřejných výdajů, $2 \%$ ze soukromých zdrojů). V současné době splňují tento cíl pouze Švédsko a Finsko, země jako Německo, Dánsko, Francie a Belgie vynakládají na výzkum a vývoj více než $2 \%$ svého HDP, Rakousko se bliží hranici $2 \%(1,94 \%)$. Česká republika vynakládá na výzkum a vývoj přibližně 1,3 \% HDP. Ve sledovaném období došlo $\mathrm{k}$ mírnému nárůstu hodnoty tohoto indikátoru, avšak s naplňováním cíle stanoveného $\mathrm{EU} v$ rámci Lisabonské strategie bude mít ČR zřejmě značné problémy - s ohledem na stav veřejných financí. Nicméně z bývalých tranzitivních zemí nových členů EU od 1.5.2004 je Česká republika spolu se Slovinskem zemí, která vynakládá na výzkum a vývoj největší podíl svého HDP. Je zde stále ještě zřejmá skutečnost, že na konci osmdesátých let mělo bývalé Československo jednu z nejrozsáhlejších výzkumných a vývojových základen (srovnatelnou svou velikostí - nikoli efektivností - s výzkumnou a vývojovou základnou Velké Británie). Přibližně do poloviny devadesátých let počet pracovníků této výzkumné a vývojové základny rapidně klesal stejně tak jako výdaje na výzkum a vývoj. V kontextu s př́ípravou na vstup do EU, s vytvářením nového institucionálního rámce pro výzkum a vývoj a s postupným obnovováním poptávky po poznatcích výzkumu a vývoje došlo k opětovnému nárůstu výdajů na výzkum a vývoj.

Mezi strukturální indikátory se řadí i úroveň dosaženého vzdělání mládeže zjištovaná jako procento obyvatelstva ve věku 20 - 24 let, které má alespoň vyšší střední vzdělání. Hodnota tohoto indikátoru pro Českou republiku byla po celou dobu, za kterou jsou k dispozici srovnatelné údaje, tj. v období 1999 - 2003 vysoko nad úrovní průměru evropské patnáctky. Jestliže na konci sledovaného období, v roce 2003, činil tento průměr $74 \%$, pak hodnota pro Českou republiku dosahovala $92 \%$. Vyšší hodnotu v daném roce zaznamenalo ze současných členských zemí EU pouze Norsko (93,3 \%), z nově přistupujících zemí 
pouze Slovensko $(94,1 \%)$. Nové členské země z řad zemí tranzitivních mají ovšem vesměs vysoký podíl mladého obyvatelstva s alespoň středním vzděláním. Nejnižší úroveň z nich zaznamenává Lotyšsko: 74 \%.

Za povšimnutív daném kontextu stojí skutečnost, že veřejné výdaje na vzdělání vykazují v zemích Evropské unie v posledních letech mírný, ale systematický relativní pokles ve vztahu k hrubému domácímu produktu. Zatímco v roce 1995 činily v zemích evropské patnáctky 5,17 \% HDP, pak o pět let později již jen 4,94 \% HDP. V nových členských - dříve tranzitivních zemích byl pokles podílu veřejných výdajů na vzdělání na hrubém domácím produktu podstatně rasantnější než v EU-15. Projevila se zde určitá konvergence $\mathrm{k}$ celoevropskému trendu $\mathrm{k}$ posunu vzdělání jako veřejného statku ke vzdělání jako statku tržnímu. Zajímavou skutečností je, že ve Spojených státech se prosazoval trend zcela opačný: podíl veřejných výdajů na vzdělání na hrubém domácím produktu pomalu vzrůstá.

V České republice poklesl podíl veřejných výdajů na vzdělání na hrubém domácím produktu na 4,28 \% HDP, tedy významně pod úroveň zemí EU-15 i EU-25. Společný účinek stále ještě relativně nízké úrovně HDP a poklesu výdajů na vzdělání na něm není pro naplňování Lisabonské strategie a posilování image ČR jako znalostní ekonomiky nikterak př́znivý.

Hrubá tvorba fixního kapitálu soukromým sektorem jako procento HDP je v rámci strukturálních indikátorů pro Českou republiku k dispozici pouze za období 2000 - 2003. Ačkoli ve sledovaném období dochází k mírnému poklesu hodnoty tohoto indikátoru, nachází se stále poměrně vysoko nad úrovní průměru zemí evropské patnáctky. Jestliže např́klad v roce 2000 činil podíl hrubého domácího produktu použitý soukromým sektorem pro tvorbu fixního kapitálu v zemích evropské patnáctky $18,3 \%$, pak pro Českou republiku dosáhl výše $23,26 \%$. V roce 2003 byly příslušné hodnoty $17,9 \%$ a 20,6 \%.

Mírou integrace se světovou ekonomikou je v rámci strukturálních indikátorů indikátor intenzity př́mých zahraničních investic (suma př́livu a odlivu přímých zahraničních investic). Jestliže v roce 1997 (první rok, pro který jsou k dispozici data), byla hodnota tohoto indikátoru přibližně na stejné úrovni jako hodnota pro země evropské patnáctky (1,2\% versus 1,1\% HDP), pak v roce 2002 (poslední rok, pro který jsou k dispozici data) byla míra investiční intenzity v České republice více než pětinásobná ve srovnání s průměrem EU - 15 (6,5\% versus 1,2\%). Během celého období neustále vzrůstala a odrážela především růst přílivu přímých zahraničních investic. $\mathbf{V}$ relaci $\mathbf{k}$ vysoké intenzitě domácích i zahraničních investic se ekonomický růst dosahovaný Českou republikou jeví jako nepř́liš výrazný - $\mathrm{i}$ vzhledem $\mathrm{k}$ tomu, že byl podporován poměrně masivní státní pomocí. Porovnání jejího rozsahu (do něhož jsou zahrnuty všechny formy státní sektorové pomoci i pomoci ad hoc) s rozsahem státní pomoci poskytované všemi současnými členskými zeměmi Evropské unie je $\mathrm{k}$ dispozici - v rámci publikovaných strukturálních indikátorů $\mathrm{v}$ relaci $\mathrm{k}$ hrubému domácímu produktu pouze pro rok 2000 . V daném roce vydával český stát na pomoc podnikové sféře $1,26 \%$ svého hrubého domácího produktu. Větším podílem přispíval stát podnikatelům pouze ve Finsku (1,39 \%). Průměr zemí EU -15 byl 0,73 $\%$, úroveň státní pomoci v dnešních nových členských zemích EU byla vesměs hluboko pod tímto průměrem (Estonsko 0,46 \%, Litva 0,57 \%, Polsko 0,37 \%, Slovinsko 0,43 \%, Slovensko 0,39\%, Mad'arsko 0,66\%).

Ke strukturálním indikátorům informujícím o plnění cílů Lisabonské strategie patří i ukazatele sociální soudržnosti. V rámci zjištování sociální soudržnosti má zvláštní význam indikátor míry rizika chudoby, zjištovanýjako podíl osob s př́ijmem pod hranicí rizika chudoby (60\% národního mediánového disponibilního příjmu). Zjištuje se ve dvou variantách: před sociálními transfery a po nich. Pro Českou republiku jsou k dispozici pouze 
údaje za rok 2001. Př́ijem pod hranicí rizika chudoby mělo v daném roce před sociálními transfery $18 \%$ osob. V porovnání se zeměmi $\mathbf{E U}-\mathbf{1 5}$ to byl zdaleka nejnižší podíl obyvatelstva. Průměr za země evropské patnáctky činil $24 \%$. Pokud jde o př́íjem pod hranicí rizika chudoby po sociálních transferech, nacházelo se pod hranicí rizika chudoby v České republice $8 \%$ obyvatelstva, průměr za země EU -15 byl $15 \%$. Nejchudší země EU vykazovaly hodnotu tohoto indikátoru podstatně vyšší: Španělsko 19 \%, Řecko a Portugalsko 20 \%. Údaj svědčí o tom, že ani ekonomická transformace, ani př́íprava České republiky na vstup do Evropské unie neměly za následek zánik sociální soudržnosti. Je ovšem třeba dodat, že pokračující nárůst míry nezaměstnanosti by mohl mít postupně za následek nepříznivý vývoj míry rizika chudoby. Stejně tak nepř́iznivě by mohly ovlivnit vývoj rizika míry chudoby necitlivé zásahy do sociální sítě - pokles sociálních transferů.

Míra dlouhodobé nezaměstnanosti v České republice ve sledovaném období mírně klesala, avšak zůstávala nad průměrem zemí evropské patnáctky. Činila 3,7 \% (průměr členských zemí EU byl na konci sledovaného období $3 \%$ ). Podíl dlouhodobě nezaměstnaných osob na celkové nezaměstnanosti dnes přesahuje $40 \%$ s tím, že existují regiony s podíly podstatně vyššími. Zmírnění tohoto problému by mělo přinést využití projektů $\mathrm{s}$ finančními prostředky z Evropského sociálního fondu. $V$ porovnání s většinou nově přistupujících zemí není problém míry dlouhodobé zaměstnanosti tak naléhavý (míra dlouhodobé nezaměstnanosti v nových členských zemích je celkově $8,1 \%$,v Polsku $10,9 \%$, na Slovensku 12,1\%). Vyšší míru dlouhodobé nezaměstnanosti má Německo (4\%), Itálie $(5,3 \%)$ i Řecko $(5,1 \%)$. Rakousko - spolu s Dánskem, Lucemburskem a Nizozemskem udržuje svou míru dlouhodobé nezaměstnanosti na úrovni pod $1 \%$.

Celková míra nezaměstnanosti v České republice se postupně přibližuje průměru zemí evropské patnáctky. Podle strukturálních indikátorů dosáhla v roce 2003 úrovně 7,8 $\%$, zatímco průměr zemí EU - 15 činil $8 \%$. Zatímco u tohoto průměru můžeme pozorovat od roku 1998 trend k mírnému poklesu (z úrovně $10 \%$ ), v České republice je trend přesně opačný: k nárůstu míry nezaměstnanosti.

\section{Reformní priority}

Ve své pravidelné Zprávě o strukturálních reformách 2004 se Výbor EU pro hospodářskou politiku zabýval stavem plnění Lisabonské strategie. Dospěl k závěru, že mají-li být do roku 2010 splněny její cíle, musí členské státy vyvinout podstatně větší úsilí než dosud a stanovil celkem devět reformních priorit ukládajících úkoly všem starým i novým členským zemím Evropské unie. Patří k nim:

1. Silná podpora růstově orientovaným ekonomickým strategiím současnou stimulací růstu produktivity i míry zaměstnanosti v rámci zdravých fiskálních politik. Urychlená implementace strukturálních reforem na trzích práce i produktů a efektivní přechod ke znalostně orientované ekonomice jsou klíčem k vyšší konkurenceschopnosti a rychlejší dynamice evropských ekonomik.

2. ̌ešení strukturálních problémů na trhu práce. Je nezbytné zejména:

- zvýšit flexibilitu systémů mzdového vyjednávání - mzdy by měly lépe odrážet rozdíly v produktivitě

- modernizovat pojetí jistoty zaměstnání (od jistoty celoživotního zaměstnání k jistotě nacházení nového zaměstnání) 
- reformovat systém podpor v nezaměstnanosti (úroveň, dobu trvání a kritéria pro poskytování) tak, aby se vyplatilo pracovat. (Výbor pro hospodářskou politiku rríká doslova: „Je třeba uskutečnit reformy, které podpoři aktivní hledání práce a sniží překážky pro tvorbu nových pracovních míst, změní nadměrně ochranářrké zákony voblasti zaměstnanosti a odstraní nepružné systémy vyjednávání“.)

3. Další redukce zbývajících bariér na vnitřním trhu EU - především v oblasti služeb a sítových odvětví. Je zapotřebí mít nezávislé orgány pro dohled nad hospodářskou soutěží vybavené dostatečnými zdroji. Státní pomoc by měla být zredukována a reorientována směrem k horizontálním cílům. (K významnému poklesu objemu státní pomoci v posledních letech již došlo. Zatímco v roce 1997 vydaly země EU na státní pomoc 102 mld. eur, v roce 2003 se jednalo již jen o 86 eur.)

4. Redukce nadměrné regulace má klíčový význam pro posílení produktivity, povzbuzení tvorby pracovních míst a podporu klimatu příznivého pro podnikání. Je žádoucí zjednodušit existující regulaci, zlepšit kvalitu regulace nově přijímané a rozvíjet tržně orientované alternativy na úrovni národních států i Evropského společenství.

5. Rozvoj znalostně orientované společnosti. Klíčový význam zde mají jednak investice do výzkumu a vývoje při současném zvyšování schopnosti podnikové sféry transformovat výsledky výzkumu do komerčně úspěšných procesů a produktů. Nezbytné je současně vytvářet efektivnější vzdělávací systémy schopné pružně reagovat na měnící se poptávky na trzích práce zejména pokud jde o absolventy vysokých škol. Ke zvýšení inovačního potenciálu může výrazně přispět i otevřenost zemí vưči přímým zahraničním investicím.

6. Stimulace zdravého podnikatelského klimatu a vytvoření prostředí, v němž se daří malým a středním podnikům. Žádoucí je institucionální rámec, který usnadňuje vstup do odvětví a výstup z něho, adekvátní nabídka finančních zdrojů pro start malých a středních podnikủ, systémy vzdělávání, které věnují pozornost podpoře kultury podnikání a odstranění nadbytečné regulace stojící v cestě zakládání nových podniků.

7. Zajištění dlouhodobé fiskální udržitelnosti, které není zdaleka dosahováno v mnoha zemích EU. (Výbor pro hospodářskou politiku říká v této souvislosti: „Voblasti penzijních systémů byly zaznamenány různé iniciativy, ale silný odpor vǔči nim mnohdy vedl $k$ jejich odmítnutí. Země si nemohou s ohledem na zhoršujicí se demografické prognózy dovolit odkládání reforem, které by měly zajistit souběžné naplňování tř́ cílů - zvýšení míry zaměstnanosti, snižení veřejného dluhu a změnu penzijních systémů. Další prostor pro zlepšení stavu veřejných financí lze nalézt v utažení schémat předčasných odchodů do důchodu. Rovněž systémy zdravotní péče a péče o prestárlé predstavuji z hlediska dlouhodobé fiskální udržitelnosti značné riziko a přesto zůstávaji víceméně beze změny. "

8. Prohloubení a další integrace finančních trhů a stimulace restrukturalizace a konsolidace finančního sektoru v souladu s Akčním plánem finančních služeb. Efektivní panevropská konkurence by měla zajistit dostatek finančních zdrojů pro podnikovou sféru.

9. Posílení kvality a efektivnosti fungování veřejného sektoru (zlepšení kvality služeb při současném zvýšení efektivnosti vynakládání zdrojů, rozšiřrené využívání internetu, otevření veřejného sektoru konkurenci, větší využívání veřejné soutěže, partnerství soukromého a veřejného sektoru). 
Na devatero přikázání adresovaných všem členským státům bez rozdílu pak Výbor pro hospodářskou politiku navazuje přikázáními specifickými pro jednotlivé země. Ty však nejprve stručně hodnotí. Hodnocení České republiky vyznívá takto: „Navzdory skutečnosti, že míra ekonomické aktivity i míra zaměstnanosti v ČR klesá, jsou stále vy̌̌ší než prümèr EU. Problémem, kterému je třeba věnovat značnou pozornost, je však strukturální aspekt nezaměstnanosti. Vysoká míra zaměstnanosti prìispivá pozitivně k potenciálu ekonomického růstu. Nepř́znivě tento potenciál ovlivňuje na druhé straně pomalý růst produktivity. Privatizační proces, který byl až na některé výjimky již téměr završen, vytvořil předpoklady pro restrukturalizaci podnikü. Konkurence na trzích produktu byla podpořena vytvořením právního rámce pro soutěž a politiku státní pomoci a je víceméně v souladu s acquis. Díky rychlétransformaci v devadesátých letech je finanční sektor rozvinutějši než ve většině nově pristupujicích zemí, v porovnání s většinou starých členských států se však nachází ve stádiu nižšího rozvojového stádia. Implementace prvních oznámených reformních kroků v oblasti veřejných financí by nesporně pomohla zmírnit růst deficitu. K dosažení udržitelnosti veřejných financí je však zapotřebí dalších krokü."

Aby Česká republika byla schopna plnit cíle Lisabonské strategie, měla by zejména:

- Vytvářet podmínky pro urychlený růst produktivity především pružnější reakcí vzdělávacího systému na měnící se požadavky trhu práce, stimulací výzkumných a vývojových a inovačních aktivit a zvýšením počtu obyvatel s vysokoškolským vzděláním.

- Podporovat podnikání a vyšší podíl malých a středních podniků na celkové produkci zlepšováním podnikatelského klimatu. Pozornost by měla být věnována především odstraňování vysoké administrativní zátěže podnikové sféry, zjednodušení procedur při zakládání nových podniků, zlepšení práce obchodního rejstř́íku, vypracování nového zákonu o konkursech a vyrovnáních, vynutitelnosti právního rámce a zlepšení přístupu k vněǰsímu financování.

- Zajistit dlouhodobou stabilitu veřejných financí, což vyžaduje reformu veřejných financí. Prioritou by měly být zejména reformy penzijního systému a zdravotní péče.

- Řešení strukturálních problémů na trhu práce s cílem zmírnit regionální disparity v nezaměstnanosti, snížit dlouhodobou nezaměstnanost a nezaměstnanost mládeže.

Zpráva o strukturálních reformách 2004 byla publikována na konci ledna 2004. Těsně před rozšířením Evropské unie o deset nových členských zemí, na konci dubna vydala Komise Evropských společenství své pravidelné doporučení členským státům pro oblast hospodářské politiky na základě zhodnocení stavu jejich ekonomik. České republice se jich dostalo poprvé. Lze předpokládat, že budou mít významný vliv na korekci směrů české hospodářské politiky.

Ekonomický růst v ČR byl charakterizován Komisí jako spiše slabší v porovnání s ostatními novými členskými státy s tím, že navzdory mnoha strukturálním změnám nedosahuje dosud svých potenciálních možností. Pohyboval se v posledních čtyřech letech kolem $3 \%$ s výjimkou roku 2002, kdy dosáhl jen na $2 \%$. Je skutečností, že některé nové členské státy vykazovaly růst rychlejší. Platí to zejména pro pobaltské země (Litva zaznamenala v roce 2003 rekordní růst ve výši $9 \%$, Lotyšsko ve výši 7,4 \%, Estonsko 4,7 \% s tím, že od počátku nového století zde tempo růstu postupně klesalo). Působil zde zjevně efekt nižší výchozí úrovně a následného dohánění, ale i efekt hlubokého propadu v letech ekonomické transformace. Tempa růstu ekonomicky nejvyspělejší nové země z řad bývalých tranzitivních 
zemí - Slovinska - se ve sledovaném období pohybovala přibližně na stejné úrovni jako tempa růstu ČR. V porovnání s průměrem zemí evropské patnáctky nedopadají ovšem statistiky ekonomického růstu v CR špatně. V roce 2001 rostly tyto země tempem 1,7\%, $\mathrm{v}$ roce 2002 tempem $1,1 \%$ a v roce 2003 dokonce jen tempem $0,8 \%$. Ještě výraznější stagnace než v zemích evropské patnáctky se projevila v eurozóně $(0,4 \%$ v roce 2003$)$, Německo dokonce zaznamenalo pokles $(-0,1 \%$ v roce 2003 stejně tak jako např́íklad Nizozemsko $(-0,7 \%$ v roce 2003$)$.

Skutečnost, že Česká republika nedosahuje takového ekonomického růstu, jaký odpovídá jejím možnostem, interpretovala Komise jako nedokončení strukturálních reforem. Podle jejího názoru se hlavní strukturální proces uskutečnil v sektoru bankovnictví a byl spojen se značnými fiskálními náklady při převádění špatných aktiv na stát. Česká republika by proto měla souběžně usilovat o dokončení strukturálních reforem, posílení ekonomického růstu a stabilizaci veřejných financí. Komise adresovala České republice celkem čty̌ri hlavní výzvy. Zní takto:

- Okamžitě zajistěte další snižení deficitu veřejných rozpočtů na udržitelnou úroveñ a usilujte o dlouhodobou udržitelnost veřejných financí

- Pokračujte v řešení strukturálních problémů na trhu práce

- Zlepšete podmínky pro zrychlení růstu produktivity

- Podpořte podnikání a malé a střední podniky

Nejnaléhavější je zjevně problém deficitu veřejných rozpočtů. Po jednorázovém započtení státních záruk stoupl deficit veřejných rozpočtů v České republice z 6,4 \% HDP dosahovaných v roce 2002 na $12,9 \%$ HDP v roce 2003. Trend k nárůstu deficitu je systematický a dlouhodobý. Zatímco na počátku přechodu od centrálně plánované ekonomiky k ekonomice tržně orientované byl státní rozpočet mírně přebytkový nebo alespoň vyrovnaný, počínaje polovinou devadesátých let (přesněji řečeno rokem 1995) začaly veřejné finance padat volným pádem do deficitu a dluhu. Posledním rokem, kdy Česká republika splňovala maastrichtské kritérium deficitu veřejných financí do tři procent, byl rok 1997. V té době činil deficit 2,5\% HDP, poté rok od roku narůstal. Třináctiprocentního deficitu $\mathrm{v}$ relaci $\mathrm{k}$ hrubému domácímu produktu nedosahuje $\mathrm{v}$ současné době žádná z členských zemí Evropské unie - ani z řad nových, ani z řad starých členských zemí. Menší nebo větší problémy s dodržováním požadavku maximálně tříprocentního deficitu v relaci k HDP má ovšem podstatná část členských zemí EU - včetně zemí eurozóny. Největší země EU, Německo a Francie se v roce 2003 propracovaly k deficitům ve výši 3,9\%, resp. 4,1 \%. Nově přistoupivší Malta zaznamenala deficit 9,7 \%, Kypr 6,3\%, Mad’arsk $5,9 \%$. Z nových členských zemí se pouze pobaltské státy se vyrovnaly s požadavkem maximálně tříprocentního deficitu.

Systematický nárůst deficitu veřejných rozpočtů ČR se odrazil v systematickém nárůstu státního dluhu. Ten je sice v současné době stále ještě hluboko pod průměrem zemí evropské patnáctky (64 \% v roce 2003) i evropské pětadvacítky (64 \% v roce 2003) a činí pouhých 37 \% HDP. Pro porovnání je zajímavé, že např́íklad belgická, řecká či italská zadluženost přesahují $100 \%$ HDP. Zarážející je ovšem trend zadlužování českého státu: z 12,2 \% v roce 1997 zadluženost každoročně vzrůstala a růst se očekává i v tomto roce (měla by přesáhnout $40 \%$ HDP). Trend k růstu zadluženosti ovšem sledují i největší členské země Evropské unie: Německo a Francie. Doporučení Komise České republice v oblasti veřejných financí je založeno na fiskální reformě, u níz by měl být významný střednědobý výdajový rámec a výkonově orientované rozpočty. Výdaje by měly zejména snižit motivaci vlády 
poskytovat státní garance, které zůstávají základním zdrojem fiskálního rizika. Druhým rizikem je nedostatek rozpočtových pravidel na regionální a místní úrovni. Z hlediska dlouhodobé udržitelnosti veřejných financí je třeba věnovat pozornost rovněž mimorozpočtovým výdajüm a rychle rostoucím výdajům na sociální zabezpečení a zdravotní péči.

Pokud jde o řešení strukturálních problémů na trhu práce, dostalo se České republice doporučení změnit systém zdanění práce a systém poskytování příspěvků $v$ nezaměstnanosti tak, aby se oslabila motivace $\mathrm{k}$ životu na sociálních dávkách a posílila motivace pracovat a současně se zvýšila regionální mobilita pracovní síly. Žádoucí je podle Komise rovněž posílit efektivnost rekvalifikačních opatření, deregulovat trh nájemního bydlení a zlepšit dopravní infrastrukturu.

K urychlení růstu produktivity doporučila Komise zlepšit efektivnost a kvalitu systému vzdělávání a posílit jeho pružnost ve vztahu $\mathrm{k}$ měnícím se potřebám trhu práce a současně zlepšovat efektivnost výzkumu a vývoje a inovačních aktivit, posílit transfer technologií prostřednictvím přímých zahraničních investic a podpořit difuzi technologií.

Odstranění nadměrné administrativní zátěže, posílení vynutitelnosti právního rámce a zlepšení přístupu $\mathrm{k}$ financování by mělo být základem pro podporu podnikatelské aktivity s důrazem na malé a střední podniky.

Stav veřejných financí v zemích EU

\begin{tabular}{|l|c|c|}
\hline \multicolumn{1}{|c|}{ Rok 2003 } & Deficit veřejných financí & Veřejný dluh \\
\hline EU (25 zemí) & $-2,7^{(\mathrm{r})}$ & 63,0 \\
\hline EU (15 zemí) & $-2,6^{(\mathrm{r})}$ & 64,0 \\
\hline Euro-zone & $-2,7$ & 70,4 \\
\hline Euro-zone (12 zemí) & $-2,7^{(\mathrm{r})}$ & 70,4 \\
\hline Belgie & 0,2 & 100,5 \\
\hline Česká republika & $-12,9$ & 37,6 \\
\hline Dánsko & 1,5 & 45,0 \\
\hline Německo & $-3,9$ & 64,2 \\
\hline Estonsko & 2,6 & 5,8 \\
\hline Řecko & $-3,2^{(\mathrm{r})}$ & 103,0 \\
\hline Španělsko & 0,3 & 50,8 \\
\hline Francie & $-4,1$ & 63,0 \\
\hline Irsko & 0,2 & 32,0 \\
\hline Itálie & $-2,4$ & 106,2 \\
\hline Kypr & $-6,3^{(\mathrm{r})}$ & 72,2 \\
\hline Loty̌ssko & $-1,8$ & 15,6 \\
\hline Litva & $-1,7$ & 21,9 \\
\hline Lucembursko & $-0,1$ & 4,9 \\
\hline Mad’arsko & $-5,9$ & 59,0 \\
\hline Malta & $-9,7$ & 72,0 \\
\hline Nizozemí & $-3,0$ & 54,8 \\
\hline Rakousko & $-1,1$ & 65,0 \\
\hline Polsko & $-4,1$ & 45,4 \\
\hline
\end{tabular}




\begin{tabular}{|l|c|c|}
\hline Portugalsko & $-2,8$ & 59,4 \\
\hline Slovinsko & $-1,8$ & 27,1 \\
\hline Slovensko & $-3,6$ & 42,8 \\
\hline Finsko & 2,3 & 45,3 \\
\hline Švédsko & 0,7 & 51,8 \\
\hline Velká Británie & $-3,2$ & 39,8 \\
\hline Bulharsko & $-0,1$ & 46,2 \\
\hline Rumunsko & $-2,0$ & 21,8 \\
\hline Turecko & $-8,8$ & 87,4 \\
\hline Island & $-1,0$ & 40,7 \\
\hline Norsko & 8,2 & 42,0 \\
\hline Kanada & 1,0 & 75,5 \\
\hline Japonsko & $-7,4$ & 154,7 \\
\hline USA & $-4,9$ & 63,1 \\
\hline
\end{tabular}

${ }^{(:)}$Není $\mathrm{k}$ dispozici.

${ }^{(r)}$ Revidovaná hodnota.

Pramen: Eurostat.

\section{Závěr}

Konvergence institucionálního rámce platného v České republice k institucionálnímu rámci platnému v Evropské unii, $\mathrm{k}$ níž docházelo v období přípravy na vstup, tedy v období posledních pěti let, nesporně působila ve směru konvergence hodnot indikátorů ekonomického a sociálního rozvoje.

Česká republika přestala být v průběhu období přípravy na vstup vnímána jako bývalá součást bloku socialistických zemí, jako země tranzitivní, jako „emerging market“ a začala být postupně vnímána jako budoucí součást jednotného Evropského trhu, jako země s politickou a ekonomickou stabilitou a postupně se zlepšujícím institucionálním rámcem. Výsledkem tohoto pozitivního vnímání je mimo jiné rozsáhlý př́liv přímých zahraničních investic. Dochází k mírnému zvyšování výkonnosti české ekonomiky. Na druhé straně Česká republika řeší v současné době obdobné problémy jako většina starých i nových členských zemí. Nejnaléhavějšími problémy České ekonomiky jsou deficit veřejných financí, rizika spojená s rozsáhlými státními garancemi, rostoucí nezaměstnanost a zvyšování fiskálního napětí v oblasti penzijního systému a systému zdravotní péče. Doporučení, která orgány Evropské komise Česká republice poskytují k řešení jejích problémů, jsou shodná nebo obdobná těm, která jsou adresována jiným členským zemím. V tuto chvíli je předčasné soudit, jak vysoká bude míra jejich účinnosti. 


\section{Literatura}

1. MACH, P.: Vstup do EU by omezil svobodu občanů. Laissez-faire, listopad 2002.

2. FASSMANN, M., KLVAČOVÁ, E., PICK, M., UNGERMANN, J., VINTROVÁ, R. a kol. autorů podkladových studií: Sociální a ekonomické dopady vstupu ČR do EU (Nové př́ležitosti, možná rizika).VŠE, Praha, 2001.

3. FASSMANN, M., KLVAČOVÁ, E., PICK, M., UNGERMANN, J., VINTROVÁ, R. a kol. autorů podkladových studií: Sociální a ekonomické souvislosti integrace České republiky do Evropské unie (Ekonomická konvergence, konkurenceschopnost a sociální soudržnost). Rada vláda ČR pro sociální a ekonomickou strategii, Praha, 2002.

4. Structural indicators (Update of the Statistical Annex to the 2004 Report from the Commission to the Spring European Council, eurostat.

5. Commission Reccomendation on the 2004 update of the Broad Guidelines of the Economic Policies of the Member States and the Community (for the 2003 - 2005 period), Commission of the European Communities, Brussels, April 2004.

6. Annual Report on Structural Reforms 2004 („Reinforcing implementation“), Economic Policy Commitee, Brussels, January 2004. 